\title{
Islam and Modernity in Crosshairs of History
}

Published:

10-07-2021

Accepted:

26-05-2021

Received:

25-04-2021
Dr Ghulam Shabbir

Assistant Professor(Humanities), Comsats Institute of Information Technology,Park Road, Chack Shehzad, Islamabad.

Email:shabbir1world@yahoo.com

Saleem Nawaz

Assistant Professor,Head, Islamic Studies Department Army Burn Hall College for Boys, Abbottabad Email: saleem.scholar@gmail.com

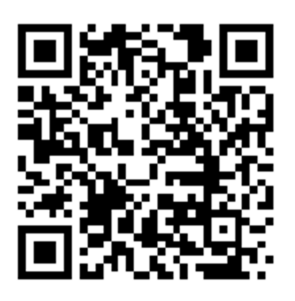

\begin{abstract}
$\underline{\text { Abstract }}$
Static view of religion is a cause of concern in all religious communities because it not only gnaws at their dynamism, more often it tends to swing history back to the old life patterns which have lost their validity and moral force. On the other hand history moves forward and seeks its direction intuitively. So, traditional view of religion collides with the forces of history in futile effort to cease the torrential stream of time. Resultantly, time or history crush them or throw them in the yokes of slavery of others who entertain ever fresh and dynamic view of history and religion. Same went with Islam. With an advent of modernity after European renaissance when Europe collided horns with Islam, once all the Muslim world submerged in European colonialism.it forced Muslim intelligentsia on serious soul search and brought forth three schools of thought the traditionalist who strictly cling to tradition even if it had relevance to the emerging realities of history or not; the revivalists who seek assuage in pristine Islam and turn the tide of history back while modernists sensing new realities harness materieux of history for moral cause and go hand in hand with history. Modernity is also a departure from mythos to the rationale so the most crucial question of todays' scholarship is whether Islam and modernity are compatible or poles apart in context of history.
\end{abstract}

Keywords: Islam, modernity, history, modernists, revivalists, traditionalists, civilizations, monotheism, moral order, orthodoxy, weltanschauung, socio-economic cum political order, multiplicity of religions, Asabiyya (group solidarity).

Religious communities the world over, be it the monotheistic traditions of Judaism, Christianity and Islam or other major religions like Hinduism are abhorrent of modernity. To a common observer, instead of successfully assimilating, rejecting, adapting and adjusting themselves to the currents of modern thoughts or accommodating the same in their folds they preferred to lock horns with modernity. Unoriginal and none creative response of religious orthodoxy provoked the hubris of modern man to such

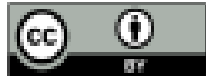


an extent that with a greater vengeance he said that God is dead ${ }^{1}$; modernity has sealed the fate of religion. Now, it is a global feel that while the unsettling modernity has outpaced socio-religious sciences, the attempt and response of religious community is like an old confused woman with a cottage on the coasts of Atlantic, busy in futile efforts of sweeping back the tidal waves of the grand ocean. While modernity has swung humanity to the threshold of unprecedented power, peace and prosperity, the supreme objects of man's desire and religious scriptures too instruct him how to manage and wield these precious blessings, then why religion and modernity instead of mutual harmony have become hornet's nest to each other.Mutual harmony is the ultimate destiny of religion and modernity; for who says " my religion is inconsistent with science has passed judgment on the falsity of his religion.Now, when "human intellect has about outgrown its fundamental categories of time, space and causality ${ }^{3 "}$; cognitive revolutions suggest new ways of looking at the problem common to both religion and science. Standing at the precipice of utter extinction modern man is entrapped in cobweb of his own intellect. This reality unfolds itself in Noam Chomsky while he says that piles of nuclear arsenals and climatic challenges are clear signs that man has proved to be an evolutionary error- either melting glaciers would destroy us or a trigger of nuclear war would suffice to erase this unlucky creature from earth. He (man) was indeed unjust and foolish (33: 72). Man "has certainly not yet fulfilled God's [primordial] command" (80:23). Recipient and donor of al-amana (Trust(establishment of moral social order on earth visit again 80:23)) both took unique risk, but man forgot that rather than being only unique privilege it is an obligation too. Man is bestowed with faculty of creative knowledge (2:30 -35) and religion and science had to walk hand in hand but religious academic orthodoxy failed to touch the pace of modernity and as a corollary both parted ways. Karen Armstrong did a commendable job by evaluating the historic developments in monotheistic religions of Judaism, Christianity and Islam viz a viz modernity more or less on same patterns but conclusion of her work seem to portray as if religion be an art work like other fine art rather than a transcendental source of human guidance by which the unseen tables and statutes of the law are revealed from the other world, together with several of the sciences of the Realms Celestial and Terrestrial and preeminently Theology 4 . Still credit or discredit of Karen's thought goes to the rich secular academic milieu which shaped her mindset. However, in this paper I have to evaluate the historicity of Islam and modernity- whether Islam and modernity are poles apart or obverse and converse of the same coin?

First to see Islam in context ofmodernity, we would have to understand the difference between Din and religion to grasp the nettle firmly. Though on different occasions Quran define Din as belief in God, angles, revealed books, prophets and Day of Judgment, still in its simplest form Din is belief in God and righteous deeds(2:62; 5:69); and anything that helps in 
establishing justice and equity in society will be considered part of Din 5 ; for élan of alamana (33:73) is the establishment of just moral order on the earth.Message of all the prophets was the same; they advocated the same Din but Sharia have been many, dictated by differences of time and place 6 . Messages of all the Prophets gush out from a same single source "the Mother of the Book" (43:4; 13:39), "Preserved Tablet" or "the Hidden Book" (56:78). Hence God's Din is indivisible; as a corollary prophethood is also indivisible: "The same Religion (Din)has he established for you as that which he enjoined on Noah-that which we have sent by inspiration to thee and that which enjoined upon Abraham, Moses, and Jesus: Namely that you should remain steadfast in religion and make no divisions therein... (42:13; also see 4:163). That is because Prophet felt obligated to believe in prophethood of all prophets whether named in Quran or not, for "and there is no nation wherein warner has not come (35:24) and "for every people a guide has been provided" (13:7). In a same vein there is no distinction between prophets (3:84; 2:285; 4:150-152), still some have superiority over others which is functional, earned rather than inherent or built-in for that goes against the justice of God.In nutshell, Din walks parallel to history (historic phenomenon) while if a certain set of values get the status of finality or permanence at a particular moment of history assumes the form of religion. So Din is dynamic while religion is static. Orthodox behaviors resist change while Din accommodates it. Issue is, the prophets' messages act as watersheds, so after their departure their followers are liable to deviate or split from the main, for divisive forces are perhaps part of Divine Mystery $(10: 19 ; 11: 18)$. Hence the people of Book who had been split or deviated from the Din e Hanif ("Straight", upright", upright monotheist who does not follow divisive forces) in initial phase of revelation are addressed as sectarians, partisans, the people who are divisive of the unity of Religion. It happens, when teaching of Din ossifies, different parties and stakeholders emerge within the folds of same religion. In early Meccan era, these Hizbs (sects) or Shiyyas (groups) are invited to join the same Din which starts from Adam and culminates in personality of Muhammad (PBUH) so that One God one Humanity paradigm might be materialized, when it falters, it sets him (PBUH)a theological problem of first order which from the start of his prophetic career goes well into the last phase of prophets life. But Divine Mystery (Mashiyyah) resolves it by acknowledging others as communities like Judaism and Christianity by dropping the terms "Sectarians" and "partisans" and the Muslims are declared as a separate community after eighteen months of Hijra in Madina.

[This is] the community of your forefather Abraham, who already named you Muslim before this; let the messenger [Muhammad] be a witness over you in this regard and let you be witnesses over mankind. So establish prayer, pay zakat and hold fast to God who is your protector-what an excellent protector and what an excellent helper! (22:78).

After it, Jews and Christians as sectsab initioare recognized as 
communities per se. Now, the issue of the multiplicity of religions gets center stage and is equally addressed. Here lies the rub of the problem. Each religion entertains actual power and strength (asabiya), at mass level, but it proves disastrous or catastrophe when it is at the cost of truthfulness. Stance of Islam is very clear, if we remove potholes of the ancient past and modern mines of the future. To secure and justify the multiplicity of religions Quran explain goodness at universal plane rather than clothing it into particular rituals or customs. "it is not righteousness(Universal Goodness) that you turn your faces Towards East or West; but it is righteousness to believe in God and the Last Day, and the Angles and the Book and the messengers; to spend of your substance, out of love for Him, for your kin, for orphans, for the needy, for the wayfarer, for those who ask, and for the ransom of slaves; to be steadfast in prayer, and practice regular charity; to fulfill the contracts which you made; and to be firm and patient in pain and adversity and throughout all periods of panic. Such are the people of Truth; the God fearing (2:177).So crux of Goodness is, to believe in God and to be on the right side of history.Now, proceed forward to understand what grand great divine mystery works in multiplicity of religions. In fact, at the outset, man would live in the paradise of divine guidance, and pay heed to the engravings on his heart (91:7-10). Then a flash of consciousness sparked on his "self" and sense of possession was enticed in him that caused his ouster from that state of mind and due to greed and diverging benefits this unlucky creature got divided into various groups. Humanity was a single community then they got divided into groups(10:19; 2:213). Was it a result of sheer selfishness or egotism on part of man or divine mystery prevails here?"If your Lord had so willed, He would have made mankind one community, but they continue to remain divided (11:118). So whether traits of divisions or disputations are intrinsic to man or earned one, in any case are best suited to divine scheme. By it a competitive world of goodness come to fore. " and We have sent down to you the Book in truth, confirming the books that existed already before it and protecting it....for each one of you[several communities] We have appointed a Law and a Way of Conduct [While the essence of religion is identical]. If God had so willed, He would have made all of you one community; so compete in goodness. To God shall you all return and He will tell you [the truth] about what you have been disputing (5:51). Hence the positive value or raison detre of multiplicity of religion is to compete in goodness, in this regard no community is God's darling; Muslims are warned of their substitute if fail to deliver (9:38). Abraham on being appointed as leader of men asked the fate of his progeny, simple reply was "We do not extend promise to the unjust ones" (2:114).Noah was rebuked over the fate of his son. In Divine scheme justice prevails. Be it an individual or community, in competition law of struggle does matter. In the world of unity of Din and plurality of Sharia (42:13) only those prevail who protect and enhance the fruits of power, peace and prosperity. If all the mankind were on the same religion, how insipid the 
world might be. Among the communities which deserves, iscoroneted. Hence, Quran vehemently condemns the election theory of Jews: that Jews or the darling community of God; for an irreversible Election of individual or community runs against the tenor of justice in Divine scheme. So exclusivist claims of Jews and Christians are condemned in Quran. "They say none shall enter the gardens except Jews (as the Jews say) and Christians (as the Christian say) (2:111). On their exclusivist claims for monopoly on guidance Quran exhorts that guidance is God's guidance $(2: 135 ; 2: 120 ; 5: 18)$. Zenith of their self- deception and haughtiness lies in the fact despite both follow or recite the Book but say guidance is exclusively their prerogative (2:113). In nutshell, so far we have tried to establish the fact that unity of Din and plurality of Sharia finds its roots in Quran (42:13). And there miraculously works divine wisdom in multiplicity of religion; for without it evaporates the milieu of 'compete in goodness', also rather than pure divine mystery inherently people intend to divide in groups due to pettiness $(10: 19 ; 2: 213)$, but final integration and spiritual homogeneity is the ultimate destiny of mankind; for Sooner or later the ethical ideal of monotheism (3:64) has to materialize on the realm of history. Pointing to this reality, Karen Armstrong strikes a redeeming note "the ideal of Quran of the "final unity of humanity" could not be realized so far because of the wars of Islam and Christianity. And later, European aggression in its various forms, could not allow the infinite meaning of the verse (3:64) to the countries of Islam in the shape of what is called Muslim Nationalism ${ }^{7 \prime}$. As a corollary, the agent of human unity (Muslim community) due to European ideological incursions got divided on artificial constructs of caste, color, creed and language.

In reality, Divine Scheme operates within the framework of multiplicity of religions or communities when Quran stays faith and goodness as the touchstone for evaluating them. "Those who believe [Muslims], the Jews, the Christians, and the Sabeans- whosoever believe in God and the Last Day and do good deeds, they shall have their reward from their Lord, shall have nothing to fear, nor shall they come to grief (2:62; cf . 5:69).Henceforth, universal goodness is recognized on theological realm, with belief in God and the Last Day as the linchpin of or necessary underpinnings. In Divine scheme only the people of excellence and virtue entertain the right to exist and prosper but active goodness (not passive) must succeed is clear from the tone tenor and tune of Quran. It keeps the battlefield hot, same goes for the community what is right on an individual level: the man can have nothing but what he strives for (53:39). In a nutshell to compete in goodness (5:51) is the major import of multiplicity of religions. How stale the world might be if without evolution of proper weltanschauung, or essential experience mankind get unified on a single platform. Different communities have to excel in virtue, and what virtue can be more valuable or precious than creative knowledge the raison detre of man's creation (2:31). Hence when God intends to bless some community, equips it with a special kind of knowledge.That is because 
that community merits the mercies of the Almighty, otherwise God does not extend His promise to the unjust ones (2:124). So, on a broader canvas, knowledge and science rules the world. Afghani utters same reality: "there was, is, and will be no ruler in the world except science. If we look at the Chaldean conquerors, like Semi-ramis, who reached the borders of Tartary and India, the true conquerors were not the Chaldeans but science and knowledge. The Egyptians who increased their realm, and Ramses 11 called Sosestris, who reached Mesopotamia according to some and India according to others- it was not the Egyptians but science that did it. The Phoenicians who, with their ships, gradually made colonies of British Isles, Spain, Portugal, and Greece - in reality it was science not Phoenicians, which so expanded their power. Alexander never came to India or conquered Indian; rather what conquered Indians was science..... Ignorance had no alternative to prostrating itself humbly before science and acknowledging its submission. In reality, sovereignty has never left the abode of science. However, this true, which is science, is continually changing capitals. Sometimes, it has moved from East to West, and other times from West to East ${ }^{\prime \prime}$. Same echoes inMaulanaMaudoodi while he says only that community is entitled to rule the world which proves itself best guardian of the garden of universe; otherwise guards are apt to be changed. Of course! God is sitting in a watch-tower (89:14). So this is mashiyya or divine mystery operational behind multiplicity of religions, I think.Any community when it becomes decadent and decrepit, after loss of moral vigor is de-seated from celestial and as a corollary territorial realms, it can prolong its existence but its exit is inevitable. Though this activity involves loss of mankind, reshuffle brings fresh blood to the veins of aging humanity and keeps the perennial moral values alive. Crux of (22:4041; 2:251) tells the same.

After Din, religion and multiplicity of religions being discussed, a cursory glance of term modernity is overdue. Modernity has many implications and connotations. To Karen Armstrong, modernity is a clean departure from hypothesis towards rationality and finds its roots in European Renaissance, which is perhaps termed as cognitive revolution by Noam Chomsky. Some perceive the wholesale rejection of religion or separation of church and state as modernity- product of secularism. Question is whether man from day first is not rational? Are we sure that rationalism of our time would be sound reality in annals of history or after millennia its major part would prove conjectural and absurd. Whether the slogan of French Revolution Freedom, liberty and fraternity was the thought product of modern man abhorrent of religion or it was religion which over millennia had infused these concepts in conscience of man through prophets and guides but religious orthodoxy distorted the same due to its vested interests. So to remove ambiguities of modernity let us get it out of its ore. A sane sage soul, Ibn e Khaldun of Modern timesDrEqbalahmad says "Modernity is a historical process. It refers to the development of societies from one mode of production 
to another, in our age from agrarian/pastoral mode to the capitalist/industrial mode of production. The shift from one to another mode of production invariably brings revolutionary changes in society. It compels a new logic of social and economic life, threatens inherited styles of life, and forces transformations in the relationship of land, labor and capital. As such, it requires adaptations to new ways of being and doing, and demands drastic changes in human values and in the relations of sexes, classes, individuals, families and communities. It transforms the co-relation and arrangement of living spaces, requires change in how the workplace is organized, how new skills are gathered and distributed and how people are governed...when this process of change sets in, older values and ways of life become outdated and dysfunctional much faster than newer ones, more appropriate values and ways of life strike roots. The resulting social and cultural mutations are experienced by people both as threat and loss. For millennia humanity had experienced this unsettling process, for example when it moved from Stone Age to the age of iron, or when it discovered fire and shifted from hunting and gathering to agriculture. But never had this process been more intense and more revolutionary than it became with the rise of capitalism and industrial mode of production. This latter development had been more revolutionary in its impact on societies than any other event in history ${ }^{9 \prime}$.Hence, change is the greatest sign of God, modernity is a natural response to that change, while Islam is the primordial religion on which Godhas originated mankind....this is the straight religion....and do not be [O Muslims!] among those who associate [partners with God], nor among those who split up their religion into sects, each sect rejoicing in what it has (30:3032). Quran calls Muhammad as a Hanif, true monotheist and his religion as the "straight religion [al-din al-qayyim"] while on the other end of spectrum paganism and sectarianism are splits or deviations from the main stream. Islam is Din, Judaism and Christianity are religions of Islam and if "for every community there had been a guide" is a guide, all are religions of Islamemanated from same source umm al-kitab (mother of all books), kitab al maknun(Hidden Book)and are destined to same destiny, unity of religion, the ultimate destiny of mankind. At critical juncture, despite prophets' painfully immense struggle to get humanity on uniform platform, Islam accepted validity and role of other religions on the realm of history. So, Islam the God's handiwork being the Din e Hanif (true religion) is in harmony to nature just as we say "magnetic needle is true to the north. At normative level, man as an artifact, shaped up by the creative hand of God, is pure, true, free, inclined to rightness, equipped with true understanding about his own position in the universe and God's goodness, wisdom and power. That is why popular tradition says man has been created on Din e Fitrat. But oblivious of his privileged status he succumbs to carnal pleasure. In nutshell, Din and modernity are both historic phenomena, so instead of supplanting or substituting each other both should go hand in hand. Instead of parting ways 
with modernity, religion should envelop it. If modern man is confident enough to dispose of his daily affairs, it is failure of religious elite who could not touch the pace of modern thought. Man has covered a long journey from Stone Age to our industrial era. Each era has had its own temper, but throughout history greatness, power, peace and prosperity has prostrated before tolerance, syncretism, openness and pluralism. Eqbal Ahmad rightly says where ideas do not clash, diverse influences, knowledge, viewpoints, and cultures do not converge, civilization does not thrive and greatness eludes. Same is élan of Islam, because when it collided with byzantine and Persian empires how successfully it absorbed and assimilated other cultures and religions in its folds.

Now, a cursory glance on origin and development of Islam would be sufficed to explore an organic link between Islam and modernity. To analyze alchemy of Islam we would have to see what was the social milieu and status of humanity at moral plane when Islam emerged on the stage of history. Let us listen to the credible voice of a great historian who states it with a galling back. "It seemed then that the great civilization that it had taken four thousand years to construct was on the verge of disintegration, and that mankind was likely to return to that condition of barbarism where every tribe and sect was against the next, and law and order were unknown. The older tribal sanctions had lost their power. Hence the old imperial methods would no longer operate. The new sanctions created by Christianity were working division and destruction instead of unity and order. It was a time fraught with tragedy. Civilization, like a gigantic tree whose foliage had overarched the world, and whose branches had borne the golden fruits of art and science and literature, stood tottering its trunk no longer alive with the flowing sap of devotion and reverence, but rotted to the core, driven by the storms of war, and held together only by the cords of ancient customs and laws, that might snap at any moment. Was there any emotional culture that could be brought in to gather mankind once more into unity and to save civilization? This culture must be something of a new type, for the old sanctions and ceremonials were dead, and to build up others of same kind would be the work of centuries $10^{\prime \prime}$. In nutshell, History with a sever fatigue, at that particular juncture was assiduously crying for fresh message from God, for the bipolar world of Byzantine and Persia was enmeshed in moral morass and carnal pleasures, perhaps reached at the point of no return, standing at the threshold of devastation and utter annihilation. The rudderless gigantic ship of human civilization had hit the sand. Humanity was simply adrift.

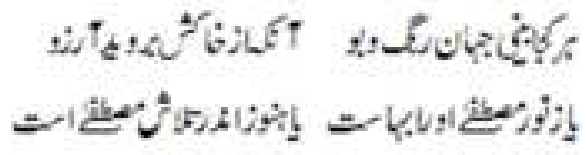

Ordinarily, in such a crisis God sends prophets. So, Muhammad (PBUH), appears at the 
geographical location where three continents of Asia, Africa and Europe meet, with program of Divine guidance among the people untouched by any of the ancient cultures, for the book of wisdom reveals that most often there is an essential discontinuity between a decrepit and decayed civilization and its successor. Most often, there is no ready-made and quick succession to a decaying civilization. Rather, God renders the slate clean and makes a new beginning than tolerate a symbiosis of decadent and virile. Therefore Iqbal rightly says that the birth of Islam is the birth of inductive logic, so to him "Prophet of Islam seems to stand between ancient and the modern world. In so far as the source of his revelation is concerned he belongs to the ancient world (last in chain of prophetic succession); in so far as spirit of his revelation is concerned he belongs to the modern world11". With intensive insight of history enhancing the same argument iqbal says "... European culture, on its intellectual side, is only a further development of some of the most important phases of the culture of Islam ${ }^{12 "}$. What it inculcated in its followers and what transpired on the realm of history alchemy of Islam reveals that it struck cognitive revolutions in human thought which still continues ${ }^{13}$ :

Wherever whatever the worlds of color and fragrance you see, or whatever the world is entertaining the hope to be marvelous, perfect or excel, either it imbued from Muhammad (PBUH) or isgroping for (in search of) Muhammad(PBUH).

It is because Quran is the greatest miracle of Holy Prophet (PBUH) and according to it God's prophets and human messengers are recipients of some special or extra ordinary power which emanates from the ultimate source of all being and which fills the hearts of these prophets with something which is light whereby they see and know things the way others are not able to. It is Amr, Preserved Tablet or Mother of Books including Quran which opens to the sacred souls. Reality speaks to them, but in case of Muhammad $(\mathrm{PBUH})$ it spoke to him in such an utmost and ultimate sense that He (PBUH) enveloped all reality and which was total in its comprehensive sweep. Summarizing this grand fact saysIbn e Khaldun.

"Quran is alone among the divine books, in that our prophet received it directly in the words and phrases in which it appears. In this respect it differs from the Torah, the Gospel and other heavenly books. The prophets received them in the form of ideas during the state of revelation. After their return to a human state, they expressed those ideas in their own ordinary words. Therefore, those books do not have the attribute of 'inimitability'. The other prophets received their books in a manner similar to that in which our prophet received ideas that he attributed to God, such as are found in many traditions. The fact that he received the Quran directly, in its literal form is attested by the statement of the Muhammad on authority of his Lord who said: 'do not move your tongue too fast to con this revelation. We Ourself shall see to its collection and recital ${ }^{14 "}$.

So, if Quran is a guide, God talked directly to Muhammad in utmost 
an ultimate sense, for all the previous prophets were nothing but Muhammad in making, and Din approaches to its logical end or evolutionary zenith. The entire gamut and drift of his prophetic career suggests he had to inject a moral order in flesh and blood of history that needed a viable socio-economico cum political order and so long as power remains on the side of corrupt political, mercantile and religious elites of Mecca that was not to be materialized. In short, this is the execution of al-amana trust(33:73), or fulfillment of primordial covenant. In IbneKhaldun's view being at the equator, land of Arabian Peninsula was equipped with sound credentials to bring forth a best of religions. Already, there existed religious fermentation, a sort of Messianism or desire for new Arab prophet (35:42); and Meccans rejected Judaism and Christianity for they wanted to excel or do better than others which is evident from Quran (6:157-58). Quran points to the presence ofHanifs (men inclined to truth) among the community who had arrived at monotheism but instead of ritualistic belief in God, "Muhammad's monotheism was, from the very beginning linked up with a humanism and a sense of social and economic justice whose intensity is no less than the intensity of the monotheistic idea, so that whoever carefully reads the early Revelations of the Prophet cannot escape the conclusion that the two must be regarded as expressions of the same experience (see 107:1-7)15". Therefore, ethical ideal of Oneness of God requires a social moral order, an ethical egalitarian order devoid of gross socio-economic disparities. If God is one, mankind is also one. When socio-economic justice and monotheistic idea part ways, ethical ideal of Tauheed reduces to mere husk, polytheism emerges and social inequalities give rise to islands of opulence in a sea of poverty, earth is filled with corruption. Therefore, Muhammad's Monotheism was, and proved springboard of social reforms. For this utmost thrust of Prophet's message was to strike one God-one humanity paradigm, and Jews and Christians are addressed as the people of the book, when appeared not getting on withthis endeavor, it sets him with a problem of first theological order. His is top-notch an enterprise to succeed, while mecca's inertia shows no healthy signs, journey of Taif multiplies that frustration. There is left no choice but to emigrate to Madina, establish there a power base to ultimately hold the control of Mecca. In Hitti's sharp but half-baked analysis it was not a sudden flight, rather well-considered strategy. But color of his lens gets hazy when in Medenese phase he terms Adhan, substitution of Sabbat by Friday, change of Qibla from Jerusalem to Mecca etc as the Arabianization of Islam ${ }^{16}$; for monotheism and agenda of socio-economic reforms and consequent egalitarianism transcends any national ideal. On the other hand, Prophet's letters to the neighboring kings amply demonstrate that Islam was bound to expand out of Arabian Peninsula. However, manipulation of the actual forces and materieux of history to the Prophets is as essential as to the worldly leaders. That is because Arabian conditioning was necessary if Islam was to develop as an effective religion in the world ${ }^{17}$ or in IbneKhaldun's words role 
of actual power and strength (asabiyya) was necessary for the initial launch of Islam $^{18}$. Therefore in Medina eighteen months after Hijra, to soothe the theological problem of Prophet's fantastic scheme of one God-one humanity, the Muslims are recognized as a separate community (22:78), moreover median community(2:141) or in utmost sense the best community (3:11o; 3:104) along with Jews and Christianity.Yet, I think it was in face of social historic forces, otherwise "o People of the Book! Come on a platform that is common between us- that we serve not except God (3:64) is of eternal import and a signpost towards ultimate human integration, which requires necessary human evolution and mature environs of globalization. Also, the principles of humanitarianism, egalitarianism, socio-economic justice, universal goodness have nothing to do with Arab nationalism rather, universal moral values. However, to make history field of Divine activity, prophet's resolve knows no limits, for he knew that mature spirituality lies in staying the course till success that is evident from vicissitudes ofinner spiritual history of prophet.

Prophet Muhammad blossomed in full glare of history; he constituted a moral social order by harnessing materieux of history. As before mentioned, emigration to Medina was a considered plan, ultimate goal was to conquer Mecca [Geneva of tribes, commercial hub of Peninsula, Vatican City of Arabs] by establishing power base in Medina, to many critics reconnaissance missions in Medina were nothing but to decorate a decisive battlefield of Badar, offensive in nature if we pay heed to Quran (8:5-7). Humiliated in dust, Meccans in 3/625 with an army of three thousands pounded Madina, and due to the disciplinary violation Muslims suffered a heavy blow, for exposed flank of Muslims was attacked. Yet when Muslims recovered, Meccans left the battlefield and marched home. So, according to the war norms victory stayed with Muslims.But the battle had shaken the hearts of Muslims to the core. God revived their morale after a fair criticism (3:139-142). What transpired, Uhd filled upMeccans cup of iniquity, while believers were assayed, their dross purified for spirituality grooms in adversity. Moral obliquity taints the intellect. In a pride, understanding turns upside down, a bar in front and a bar behind, so the victim can neither progress nor turn back. Injustice is basically reflexive. On the other hand God never lets the power of discernment or correct judgment of his party (believers) die, keeps moral fervor a perennial force alive. Two years after Uhd, in 5/627 Meccans with an army of ten thousands at the instigation of Jews of Khyaber again laid siege to Medina. It was an army of confederates, therefore called Ahzab: polytheists, Beduins and Jews etc hatched plan to occupy Medina. Resolve and discerning power of the believers came victorious, and the ditches dug in front of exposed parts of Medina proved ultimate graveyard of Meccans' efforts to thwart Muhammad's movement for establishing moral order.Jews were meted out justice. Now, prophet zeroes in on Mecca. A plan for lesser pilgrimage was something more than a mere ritual, a power display, sublime aggressive move rather than protective posture which points toward political acumen of 
prophet (PBUH). It was a calculated risk to take stock of situation in Mecca.it culminated in Pact of Hudaybiya. Quran termed it as manifest victory; for a cool courage brings such reward. On one side Islam was recognized as an equal power, on the other it opened door for free promulgation of Islam throughout Arabia and thence through the world. Not the least, by striking truce prophet blocked any imminent danger of joint adventure against Islam. So after crushing snake (conspiracies of Jews) in backyard, prophet was waiting in the wings to take out the last thorn in the side of Islam. Muhammad and his companions performed minor pilgrimage next year in 7/628. However, in 8/629 Muhammad seized Mecca on high moral grounds; for Meccans were party to a conflict in which their opponents had alliance with Muslims.Meccans negotiated a peaceful surrender, now the whole of Arabian Peninsula was under the feet of Prophet. At culmination of this decisive victory, having pieces of stale soaked bread at house of Umm e Hani he said self-abnegation is my pride. So self- effacing he was that he referredevery bit of his achievement and success to God (110:1-3). Now Arabs embraced Islam en mass except city of Taif and the tribes of Hawazin presented stiff resistence. Here in battle of Hawazan first time despite larger in strength Muslims felt themselves earth-less, but succor of God came and they snatched victory from the jaws of defeat.Here disruption occurred on division of beauty, but conflict resolution bears testimony to the broad gauge magnanimity of prophet.Ansars objected: ours are more sacrifices, while new converts are getting more from booty. Prophet asked! Were you not poor, then due to me God made you rich? All replied, yes of course! Had not mutual dissentions sapped your lives? I resolved the same and you got unity? Alright replied Ansar! Prophet said you are speaking half-truth. Now I acknowledge your favors and you say yes! Was I not helpless and you provided me refuge? Was it not because of you that we became rich? Is it not right that today the whole Arabianpeninsula is under my feet because of you? In standing ovation they cried yes! Then is it not good that they should get booty and Muhammad goes back to Medina with you. We accept it O prophet of God was a reply. Prophet made Medina his permanent seat. From here in 9/630 conducted a campaign against northern Christian Arabs of Transjordania.Even a month before his death had ordered expedition to the North. Suffice to prove that Islam was bound to expand out the boundaries of Peninsula, letters to the emperors and kings of Persian and Byzantine Empire are icing on the cake. Accustomed to nationalism, orientalists are on futile effort to prove that these campaigns were no more than to free Arabs from Persian and byzantine colonialism. Their rigged intellect sees shifts in Muhammad's stance every now and then, but fact is there we not see even an iota of change in rock solid integrity and character of prophet, Meccan verses (29:1-10) elaborate enough that Medinese and Meccan phase of Prophet's life is highly interfaced and had organic link rather than even juxtaposition of two discrete periods. Though, revelation helped on crucial stages, yet it was razor-sharp intelligence 
grounded in faith, painfully honest and ambitious enterprise of moral order and armed to the teeth statesmanshipof Muhammad that bequeathed to humanity both a set of ideals and a concrete way of achieving those ideals, which still constitute the best solution for human crisis.It is easy to travel with the speed of clouds; easier to weigh the earth, but understanding of human affairs is the complex task. It was intense spirituality and rigorous pragmatismof Muhammad which bent history to a definite course.

Departure of prophets would prove water-shed event in history of religions. After them foundational phase gets over, interpretive phase sets in. Being revolutionary in nature, first phase,period of inception strikes hard on status quo, sclerotic modes of life depart and new values strike roots. In this 23 years' period the complex edifice of the monopolies of religious-politicocum mercantile elites crumbles to dust and second era the period of collection and application sets in. This era brought Persian and Byzantine empires under the pale of Islam and assimilative-deductive thought activity remained élan of this period. Wherever, whatever was necessary Islamassimilated, rejected and adjusted itself to the new currents.In this 29 years period which straddles even the major portion of third period of Islamic history there was an organic link between Sunnah,Ijma and Ijtehad, which later on reverses and Ijtehad comes to a standstill. Second period constitutes the time of four righteous caliphs. Endeavors of Omer the second caliph whom Shah Wali Allah says Mujtahid e Mutliq state, to them Ijtehad was to devise strategies which are supportive to moral life and pave the way for progress, peace and prosperity. The third era of Islam commences from Omayyad dynasty and ends at the start of Seljuk period. This the most creative phase may be termed as the interpretive period of Islam, major impulse of this phase involves challenges and responses. During this period emerged different schools of philosophy, law and mysticism in Islam. At initial phase in seed of Islam there was an organically linked whole complex of fiqh, Kalam and Tassawuf; for (Tafaquhufiddin) was employed for intellectual efforts in all the three domains. Despite being a book of Human guidance on morality Quran regulates the crucial human affairs by concrete laws, Similarly despite its major thrust on faith- in- action it inculcates sort of spirituality in believers( see the mystic experience of Prophet in 17:1; 53:1-12 and 13-18;81:19-25), also it elaborates key theological issues but the first generation had nothing to do with such problems because its major relevance was with the do's and dont's to construct a socio-moral order. Naturally the seed of Islam had to sprout into these different disciplines which were present in a single whole in initial phase. With outward expansion of Islam Kufa, Basra in Iraq, Fustat (present Cairo) in Egypt initially cantonment areas developed into melting pot of knowledge and sciences. There developed three traditions: the tradition of Hijjaz, Iraq and Egypt (it included Africa that time). Here in Hijjaz the dominant factor was Hadith and Sunnah of Prophet therefore called Ahl-alhadith. The major thrust of Iraqi tradition was on opinion therefore termed 
Ahl-al-Ra'ye.Shafi the pupil of Malik Bin Anas, teacher of Ahmad Bin Hunmble and contemporary of Al-Shaibani held the seat of Cairo and adopted rather synthetic approach to devise Islamic Jurisprudence.Before Shafi's formulation, there was an organic link between Sunnah, ijtehadand ijma.Sunnah in earlier generations of Islam was considered as the ideal or normative behavior of community. It was a tradition that preserved certain moral value and if preservation of thatvalue demanded ijtehad it was enhanced and that product of ijtehad also calledsunnah then a sort of concensus(informal ijma) developed on that Sunnah, in a final analysis it was a continuum phenomenon. That is because SnoukHurgronje held that the Muslims themselves added to the Sunnah of the prophet until almost all product of Muslim thought and practice came to be justified as the Sunnah of the prophet. To some, in early period Sunnah meant the practice of the Muslims themselves.This informal ijma did not rule out difference of opinion. Sunnah-ijma of Madina differed from that of Iraq. Even within each region differences existed, and in a natural way ijmawas being arrived through differences in local usage and different interpretations.Fresh thinking and interpretation was going on, but in later second and especially third century Hadith develops into an overwhelming movement and substitutes the twin principles of Ijtehad and ijma and relegates these two to the lowest position and severed the organic relationship between the two. This came under the exigencies of time and space, because Sunnah of different regions- Hijjaz, Iraq, Egypt etc became divergent on almost every issue of detail. It was purely for administrative purpose to struck uniformity in Muslim empire. Otherwise, gauge the flexibility and broadness of Sunnah from a single instance that when community was plunged in labyrinths of Predeterminism and Free Will (Jabrites and Qadrites schools), Omayyad caliph Abd-al-Mailk b. Marwan asked KhajaHasan-al-Basri is there any hadith regarding the issue. He replied in a letter that though there is no hadith of the prophet in favor of the free will and human responsibility, nevertheless this is the sunnah of the prophet. It means behavior of prophet and his companions implicitly contradict the doctrine of predeterminism. It shows Sunah of Prophet to earlier generation was rather a pointer in a direction than laid out series of rules. To it Quran refers" of course! You have indeed an ideal model in Apostle of God (33:21). This was the early thought activity of the Muslim, and ijtehad and ijma were its essential complements. However, it was Shafi who gave the status of finality to Ijma, and it became necessarily formal and total one, to strike equilibrium and uniformity in the empire. Ijma ceases to be as dynamic ongoing democratic process. Itbecame static and imposed one process.Sunnah rather than a general directive became absolutely literal and specific which relies on Hadith. In his principles of Islamic Jurisprudence, next place he assigns to Sunnah of the Companions, especially first four righteous Caliphs. In third place in his Schema comes Ijma, lastly he accepts Ijtehad. By reversal of natural order: Ijtehad-Ijma into Ijma-Ijtehad organic link finishes. Today, 
even in modern constitutional democracies no clause of the constitution gets the status of finality, if need arises it can be amended or removed by new consensus, but our consensuses of earlier generations or latter renovators are final in nature even though we know that sometimes Omer's Ijtehad on face value seemed contradicting Quran but on broader canvass fulfilling the moral elan of Quran. Distribution of booty on conquest of Iraq is a case in point. So, "Al-Shafi's genius provided a mechanism that gave stability to our medieval socio-religious fabric but at the cost, in the long run, of creativity and originality ${ }^{19^{\prime \prime}}$. It was in a fetus of this scheme to get Islam passive entity rather than an active force or being master of its own destiny.

However, in the same third period of challenge and response of Muslim history which constitutes four centuries from the end of righteous caliphacy (661/61) to the beginning of Seljuk (1055/447) proved seed bed of philosophic, legal and mystic traditions along with history, hermeneutics, seerah, Hadith, literature, theology and other disciplines. This period evoked internal and external challenges and presented successful responses. During the wars of Ali and Muayia a fanatic group named Kharijites came to fore that marks the first schism in history of Islam. It presented a first ever extremist group which spilled blood of innocent Muslims on menial issues of dogma. Highly venerated in orientalists formulations as first social democrats in Islam, for to them any righteous guy was entitled to be caliph even if he is slave, but why does western academic orthodoxy ignores their extremist formulations. They slaughtered countless Muslims on pretext of difference of opinion, or their definition of Islam.If their strict observations had been applied, Muslims would have been reduced to smaller community. It was high time to define Islam, Muslim. This challenge brought forth the first philosophic school of Murijites( English equivalent postponement or hope). To counter this severe tumult,Murijites said anybody who says KalmaTayyiba and count himself member of Muslim community would be considered Muslim, and so far as his conduct is concerned it comes in the domain of God to decide on the Day of Judgment. It is hoped God would treat him mercifully. On one hand it countered Kharijites' tumult successfully; on the other it gave carte blanche to the Omayyad and later dictatorial regime. With the conquest of Persia Zoroastrianism andMagian thoughts were seeping into Muslim Ideologue, Sabr, Taqdir, Tawakkaland other terminologies lost their original meaning and vigor. Now Sabr takes on the meaning to forebear the excesses of Omayyad caliphs, Taqdeer stayed as something pre-written fate of humanity and Tawakkal means without struggle hoping best in future.Murijites developed into new school of Jabarites which believed in predeterminism. It justified injustice and tyrannies of Omayyads. It gave rise to moral perversion and apathy. Its antithesis Qadarite came to fore whose major thrust was free-will. It became torch-bearer of Amar bilmarufwanahianilmunkir and said man is free in his thought and action, so responsible for his deeds. Omayyad executed its two founders one after other. 
But Damascus had no recipe tosilence the pious sermons ofHasan al-Basri the staunch supporter of Qadarites.Qadarites struck a beautiful balance between the indefinite powers of God and human free-will-the most difficult question of philosophy and religion. However, the efforts of this school were confined to the religious realm, while Kufa, Basra in Iraq and Fustat in Egypt have become melting pot of philosophy and sciences. Spain, central Asia, Iran and Indus valley were under the pale of Islam, two great empires of Byzantine and Persia have crumbled to dust, former because of its religious colonialism, the latter due to hotchpotch of internal conspiracies .Now, Zoroastrianism,Maniism, Mazdakism, Budhismalong with Judaism and Christianity had surrendered their political sovereignty, historically religiocultural sovereignties had been the toughest area to withdraw from. Nestorian Christians had translated Greek philosophy and ideas were seeping into Muslim discourse, Qadarite's mere religio-moral school of Hasan alBasari proved insufficient to withstand queries of Greek dialectics, time was ripe for turning the practical religiosity of Arabian Peninsula into dialectical theology.Hijjaz soon after separation between state and religion in Omayyad period, or shift of capital first by Ali from Medina to Kufa, then by Omayyad to Damascus finally by Abbasid to Baghdad confined itself to Sunnah and Hadith, whatever law developed there was due to interest in these disciplines. Hence exigencies of time brought forth fourth school of Islamic philosophy called Mutazilla. The first rationalist school of Islam was an utter response to external challenges which weaved out fabric of Islamic theology: oneness of God, free will and attributes of God, justice, reward and punishment, good and bad etc with such a finesse that defies description, but the major challenge to any movement is to maintain equilibrium, they lost it and stayed intellect at par with revelation. Philosophy is a double edged sword its one end proves something the other can equally refute it. So their utter reliance on rationale invoked reaction on the side of fundamentalists. The fifth school of Islamic thought called Asharite emerged on the scene. Its founder Abul-Hasan alAshari was student of Imam Ahmad B. Humble, who himself was pupil of Shafi the student of Malik b. Anas; the first authentic compiler of Hadith groomed in simple religious tradition of Hijjaz. It was in a sense equivalent of reversal of the religious evolutionary thought. Perhaps once more, literalism, fundamentalism, decontextualized Hijjazi tradition reigns supreme on realm of theology. Free-will sacrificed on the altar of indefinite powers of God to an extent thatman became an agent of God's plan. It flatly refused free will of man. That even resonates well in an eighteenth century Indian poet Mir.

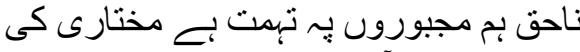

$$
\begin{aligned}
& \text { جابه بين سو آب كر ـا بين بم كو عبث بدنام كيا }
\end{aligned}
$$

Even when Asharites honed their wit with dialectics to counter Mutazila, were equally rejected by extreme right wing of orthodoxy.Asharite and ahl-hadith animosity failed to struck an agreed upon theology. However, in this tussle Tasawwuf and philosophy absorbed the best of Muslim 
minds.Tasuwwuf became a great appeal against orthodoxy; for it ceases to be an ever innovative force. From the time of righteous caliphs to the installment of Seljuk, along with schools of philosophy, law (fiqh) also progressed by leaps and bounds. From the beginning of second century to the end of third century many law schools flourished to administer an overwhelmingly large empire, von Kremer attributes half of Muslim triumphs to our doctors of Law, and stays Muslim Law well-coherent next to the Code Romane ${ }^{20}$. Sunni Fiqhs of Abu-Hanifa (d.150),Imam Malik (d.179), Imam Shafi (d.204), Imam Ahmad b. Humble(d.241), and Shia fiqhs of Imam Jaffar al-Sadiq(d.151) and Imam Zaid bin Ali bin Hussain Bin Ali (d.122) came to fore during the same time. They devised and harnessed different geographies of legislations. Even principally pupils more often differed with their teachers;Hanafites relied on Principle of preference, Shafi on reason or logic, Malikites on public good while equity had been the part and parcel of all schools.All schools of fiqh were sprouting naturally on the realm of Islam, and followers of one fiqah were at ease to follow the others if need arises.Soon after it we enter fourth era of Islamic thought that begins with the rise of Seljuk Dynasty and ends at the death of Imam Ghazali. This would be termed as period of standardization and consolidation of Islamic thought. In a sense tree of Islamic civilization blossomed at full zenith, fruit of each discipline was artificially ripened by Ghazalianentrepreneurship. Before him, in third period of Islamic thought, inductive school of Hanafites and deductive school of Shafites along with other fiqh schools catered well to the needs of developing and ever expanding political realm of Islam. With Ghazali dawns the school of Maqasid, instead of narrow interpretations of law ( qayas, istehsan, MasalihMursalahetc) the higher objectives of law are formulated. In fact, by operating synthesis of the deductive and inductive approaches before them, extracting and classifying the higher objectives of law a new Usul school came to fore.Fiqah as opposed to its earlier status as in earlier generations was an all-out intellectual effort equivalent of Ijtehad perhaps turned to Roman equivalent of Jurisprudence. Abu al-Maali al-Juwayni(d. 478/1085),mentor of al-Ghazali (d. 505/1111) laid down the foundation of school of Maqasid by categorization of rulings according to divine law giver's intentions and the effective causes of the rulings by classifying them vertically according to their degree of importance and priority identifying five different levels(p.61). In his horizontal categorization come religion, life and chastity. Al-Ghazali his pupil takes up this Herculean task to its logical conclusion. Though his link from school of Shaffi,he opted for Istehsan of Hanafite and Masalih al-Mursalah of Malik (in absence of relevant texts, an utter reliance on public interest). He says: " ....what we mean by maslaha is preserving the objective of law (shar') that consists in five ordered things: preserving religion (din), life(nafs), reason (aql), progeny (nasl) and property (amwal). What ensures the preservation of those five principles is maslahah, what goes against their preservation is mafsadah, and preventing it is maslahah ${ }^{21 "}$.Ibn-e-Qayyam says "the basis of 
Sharia is wisdom and welfare of the people in this world as well as the hereafter. This welfare lies in complete justice, mercy, wellbeing and wisdom. Anything that departs from justice to oppression, from mercy to harshness, from welfare to misery, and from wisdom to folly has nothing to do with sharia ${ }^{22}$. These sources feed well to the latter scholars, some added honor to five categories. Ghazali proved springboard for latter reflections well up to the time of Shatibi (d.790/1388).Ghazali, with his spiritual itinerary struck harmony among ever feuding stakeholders of mysticism, law and kalam. "He not only reconstituted orthodox Islam, making Sufism an integral part of it, but also was a great reformer of Sufism, purifying it of un-Islamic elements and putting it at the service of orthodox religion. As such he represents a final step in a long developing history. Sufism received, through his influence, the approval of ijma, or consensus of the community. Islam received a new vigor of life and a popular appeal which won large areas in Africa, Central Asia and India. Henceforth, often a great theologian and a great Sufi was one and the same person, a development which produced in due course a series of original thinkers who reconstituted Muslim theology on a new and more integral basis, than the old formal Kalam ${ }^{23 "}$.To date from Morocco to Malaya madaris of Islam are catechism of the syllabus formulated by Ghazali.Dew drops of his theological ideas diffused wellonto the thirsty theological realms of Christian West.To Hitti, works of Ghazali as Fatihat al-Ulum, tahafutalphilasifah, al-Iqtisad fi al-itiqad, IhyaUlum al-Din, al-Mustasfa min Ilm al-Usuletc marked influence on Jewish and Christian scholasticism. "Thomas Aquinas, one of the greatest theologians of Christianity, and latter Pascal were indirectly affected by the ideas of al-Ghazali, who of all Moslem thinkers came nearest to subscribing to Christian views. The scholastic shell constructed by al-Ashari and al-Ghazali has held Islam to the present day, but Christendom succeeded in breaking through its scholasticism, particularly at the time of the Protestant Revolt. Since then the West and the East have parted company, the former progressing while the latter stood still24".Actually, in dictatorial era people find solace in mysticism. That was the case with alGhazali. His spiritual itinerary turned him into harmonized blend of spirituality and pragmatism. In his constructs, interests of community and Seljuk find conformity, in-depth analysis show Seljuk come prairie while community posteriori. Being Sufism in vogue, Ghazali attacked philosophy in his Tahafut al-philasifah. His chief opponent Averroes, the Spanish thinker of Islam, unconditional guardian of Aristotelian school's doctrine of immortality of active intellect and its grand interpreter, somewhat, in defense of Greek thought rather than philosophy by writing tahafut al-tahafah punched above his weight. On the other hand Ghazali based religion on philosophical skepticism. In actuality, Quran stays ears, eyes and fuad (faculty of heart, mind cum spirit) as essential tools of knowledge (32:9). Former, eyes and ears help more in empirical sciences, latter the fuad, faculty of heart in its mature spiritual essence the locus of revelation, grasps metaphysical aspects of 
reality, guzarjaaql se aagay... dil e binabhi. The golden mean of information brought by ears, eyes and fuad points toward reality.Ghazali's spiritual itinerary catapulted him to assert more reliance on fuad,ibn-Rushd immersed himself in scientific school of Aristotlebased on empirical sciences in its major import. In other words he stood in the camp ofMutazila. That is because East feeds on Plato and Ghazali, while West on Aristotle and Averroes, former spiritual, latter empirical in its outlook. East is more concerned with his self, God and world, and West's attitude is this-worldly. However, except excessive reliance on predeterminism, Asharite thinkers chose constructive path and paved a way for modern forms of idealism, though major thrust of their movement remained to defend orthodoxy with a weapon of Greek dialectic, which would have proved futile if Ghazali had not endorsed it. History bears witness that major bulk of humanity tends to shake balance of thought. Same happened with Ghazali's constructs, he was construed as opponent of philosophy or streaks of his thought did so, with his departure Muslims banned philosophy on themselves, even if al-Ghazali in his profound reflections terms the universe as "outspread book (al-kitab al-manshur)" which is theological as well as physical mirror of the "written book (al-kitabal-mastur)"; for Quran itself vociferously points towards the signs spread in cosmos. Hats downto the resilienceof orthodoxy, which takes of its choice and leaves other under its hat from these genies of Islam! If someone claims that Deoband and its clones are followers of Shah Wali Allah he is simply ignorant of Shah's thought. Same is the case of Ibn e Tamiyyah's followers. Ghazali leaves a wide scope for generations to come, to continually exhaust their faculties of ears, eyes and intuition (fuad) in exploring harmonies between revealed book and unfurled revelation (universe) to resolve their theological as well as practical problems; for the revealed text neither stifles nor directs the mind, it liberates it at the heart of the Universe: the world speaks by itself, autonomously, and it is human intelligence's task to understand its language, vocabulary, semantics, rules, grammar and grand symmetry (67:34) in creation and order. In nutshell, text (kitab-al-manshur) and context (kitab-al-satur) rather than contradicting or supplanting envelop, augment and reinforce each other.But whether it is intellectual lethargy of his followers or his misconstrued constructs, or his apparent attacks on philosophy, Ghazali is also maligned in some academic circles who say "but for Al-ashari and alGhzali the Arabs might have been a nation of Galileos, Keplers and Newtons. By their denunciations of science and philosophy, by their exhortations that besides theology and law no other knowledge was worth acquiring, they did more to stop the progress of the Muslims world than other Muslim scholiasts. And up to this day their example is held forth as a reason for ignorance and stagnation ${ }^{25}$ ". Anyway, fourth period of Islamic thought might be termed as period of consolidation and standardization, product of Ghazalian entrepreneurship.

Henceforth, after Ghazali, ushers in the fifth period of Islamic thought 
termed as period of stagnation and blind imitation. To some extent it still continues with some extra exceptional aberrations such as those of alRazi(d.606/1209), al-Bayddawi (d.685/1286), Ib as-Subki(d.771/1369), atTufi(716/1316) and Ibn e Taymiyyah (d.728/1327), al-sutiand in near past Sarhandi, Shah Wali Allah etc.All these proved harmless ozone's filtered rays for the glacier of our thought or gradually got absorbed in the same.For alAsharite'spredetermnism got its zenith in al-Ghazali and al-Razi's constructs when they vied with each other in producing ever fresh arguments to prove that man can be said "to act only" metaphysically, not really, since the only real "actor" is God? Today, any real theorist of Islam needs not to frighten of fishes in the pool because crocodiles have devoured them. However, two centuries after Ghazali a Spanish scholar Shatbi (d.790/1388) emerges to scene with a theory and methodology that transcend legal school and he integrate those tools of inductive and deductive logic devised by earlier schools. He integrated into his approach, all the works and methodologies produced in the meanwhile by scholars from the other schools- Shafi, Hanafi,Hanbali, Zahiri (with IbnHazm, died 455/1064 ) and the various Shii schools. His ultrasynthetic approach enhanced the epistemological frame-work of school of objectives with a new dimension: Maqasid al-Mukallaf stemming from the accountable [man] along with earlier specified as maqasid al-shari determined by Divine Lawgiver. Further human interests are classified into primary and secondary (maqasid-al-asliyyah ,maqasid al-tabiyyah)He struck equilibrium and collapsed extremes into middle. His insight of history compels him to say that though an action may be deemed permissible, recommended, lawful, objectionable or even lawful in itself, its status can be changed according to context in which it is considered and judged. For example, caliph Omer's decisionto suspend the punishments for poor thieves in times of famine, was based on justice rather than literal implementation. If it be, it would have run against the higher objective of justice, since the poor thieves have been twice victimized. Similarly, while attacking BanuNadhir, cutting tree was to strengthen the seizure of the very tribe apparently violation of (2:205) but context changed its very status.Furthermore, to al-shatibi, Quran of Mecca is of universal import while of Medina is rendering, illustration and concrete implementation of those principles in that historical context.To great minds of Islam text determines major principles and sometimes states number of details, while sunnah's function is to detail, clarify and illustrate the same. It liberates Quran from the specific contextual interpretation of Medina period. Those renderings cannot close off the Quran and the Divine Lawgivers' higher, universal objectives into a particular, historically dated, and quite specific interpretation.On these grounds, Omer refused to divide the lands of Iraq among soldiers as booty against the literal interpretation of Quran and Sunnah in favor of tenor of Quran and an Ideal model of the prophet (PBUH); for both converge on social justice and fair play.Omer buttresses his stand by (59:9-10).In sum total, Shatbi toe the framework of Omer the second Caliph an 
absolute Mujaddid and the first critical and independent mind in Islam who, at the last moments of the Prophet, had the moral courage to utter these remarkable words: 'The Book of God is sufficient for us'26.However, in fifth period of Islamic thought of blind imitation and stagnation moral apathy not only slipped Muslim's grip on realm of power, spring of their fresh thought stopped gushing out, especially from $18^{\text {th }}$ century on, once master of their own destiny were serving the history of others when industrialized imperial Europe with fresh vigor locked horns with empires of Islam.

During the heydays at outset, Muslims were psychologically invincible, at the helm, politically masters of situation, and Byzantine a spent force, so the dramatic expansion of Islamic dominance occurred at the expanse of Christendom. For seven hundred years Muslims ruled Spain, if Safavid had not been in Persia, Ottomans had been brought all the Europe under the pale of Islam. Safavids' power at the backyard rather than rival forces rendered Ottoman's occupation of France unfulfilled task. Hence, it is only Islam with which West has fourteen centuries fluctuating history of territorial, religious and cultural boundaries. Crusades and wars of Islam obliterated sense of decency and unbiased appraisal of each on both sides. Even Quran and Prophet(PBUH) were not spared, though Muslim by faith are obliged to venerate Biblical chain of Prophets, so better sense prevailed there, yet Judaism and Christianity was misjudged and misrepresented by medieval Muslim thinkers, for they saw Jews and Christians from the prism of Medenese phase. It obscured their vision of any possibility of mutual accommodation. On the other side, rivalry of Islam was too deep seated in psyche of Christian Europe that at the end of First World War while conquering Palestine commander of allied forces Lord Allenby saidthat today the crusade is over.In a terse and nude analysis, centuries old fluctuating history of sea-saw struggle between Islam and Christianity took a new turn with Napoleon Bonaparte's invasion of Egypt in 1798 and British colonization of Mughal India in 18 th and 19th centuries and break-up of Ottoman empire proved a last nail in the coffin of Islam's political cum military power. Henceforth, moral epistemology of imperial Europe (white man's burden, superman, survival of the fittest, now clash of civilization) divested even last speck of confidence, a loss greater than political one for the later thrives on the former. Russia in our times is on resurge (take her stand on Syria, Ukraine), it's politico-economic cum military demise at Asia's heart (Afghanistan) failed to diminish her huge ego.We lost our wings in cage, and are unable to grow even after freedom. Self-cognizant individuals and communities pile stock of straws while in cage, and weave out nests on freedom spree. However, Western long hegemony caused intense soul search in Muslim world, it is norm of history when a civilization hits the rock bottom, and at that point of fundamental crisis it evokes three responses in its adherents. First the revivalists who seek solace in pristine Islam, second the traditionalist who unconditionally surrender to the tradition and are rather apathetic to future 
believe in uniform decline of community. The third one is modernist, harmonized blend of reason and tradition, the class of enlightened and progressive intellectuals. Be it the Jinnah of Pakistan or Jamal Abd al-Nasir of Egypt, Ahmad Sukarno of Indonesia or HabibBourguiba of Tunisia are a few and familiar who did marvelous job to get rid their communities of colonial yokes. Extra-exceptional among them is Mustafa Kemal who gave coupe de grace to imperial Britain in Cyprus, ignominy of which haunted Churchill till last breath of his life. However, soon after de-colonization mushrooming of Marshal Law regimes in Muslim world from Morocco to Indonesia swept the tide of such a people and brought forth holy lot of traditionalists easily dovetailed with dictators. Revivalists like Alice in wonderland have continually to wander in wonders; for the idealist knew only to sacrifice without having pearl of their choice. Be it the revivalist movement of 1857 freedom war or before it the puritanical movement of Sayyed Ahmed Brailvi, Ikhwan of Egypt or Jamaat e Islami of Pakistan. To many observers, it was holy alliance of orthodoxy, feudal elite and military which forced secession of Bangla Dash to get rid of progressive majority. The alliance still continues. Doctrine of Necessity still looms large over Muslim polities; for it was al-Ghazali and his successor IbnJamma who said that public tolerance of bad ruler was preferable to anarchy and civil war, on the other side theological authorities of Islam like al-Mawardi, al-Baghdadi and al-Baqilani held that an unjust and unrighteous ruler should not claim obedience against just contender. But Ghazalian constructs reign supreme on Muslim's mindset and Muslims are hostage to the tripartite alliance of dictators, clergy and Sufis. The same three elements have taken wind out of Islam's sails.

To be back on terra firma, Muslims need to grapple with these categories and grasp the nettle firmly. For this, Muslims have to recourse to Quran with an independent mind; infer laws of history according to dictates of time rather than blindly following medieval constructs; for our problems and constraints are different in our own milieu. Though Quran claims it is easy to comprehend, yet it is as deep as life itself, for it took twenty three years to be revealed.The simplest complex, Quran is as straightforward and coherent as life itself. In Churchill's phrase life is riddle wrapped in mystery, inside an enigma. So,to take Quran as lifeless dicta would be equivalent of "crushing its gossamer wings to powder". In this transitional period of Islamic thought idealists, the stupid friends of Islam entertain proclivity to depreciate materieux of history (which even the Prophet of Islam was bound to harness), consequently are unable to bend history to a specific definitive course. Future of Islam lies with the modernists who can make history field of Divine activity by working with the complicated twists and enmeshing folds of the materials of history.Pragmatists or non-idealists know only the exterior of life on cost of higher values. Quran vehemently exhorts that man instead of social animal is a moral being. Philosophy in our curricula has to cease as a disciplina non grata; a perennial intellectual need has to be allowed to flourish 
for its own sake and for the sake of other disciplines, since it inculcate a much needed analytical critical spirit and generates new ideas that become important intellectual tools for other sciences, not least for religion and theology. At this crucial juncture, Islam needs ta'miri school of Farabi and Ibn al-Arabi (not to reinvent them but like them bring forth new ideas) rather than Takfiri school of Ibn e Taimiyyah and Ghazali, however political emancipation is first step toward that destiny, declining moments would bring forth new Ghazalis and Ibn e Taimiyyahs. Societies devoid of socioeconomic justice can be Muslims but never be truly monotheistic at all.

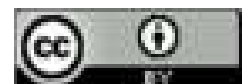

This work is licensed under a Creative Commons Attribution 4.0 International License.

\section{References}

1. Netche claimed so.

2. Keddie, Nikki, Islamic Response to Western Imperialism, University of California Press Berkeley, Loss Angeles,p.107, California library Reprint Series 1983

3. Iqbal, Reconstruction of Religious Thoughts In Islam, published by JavaidIqbal son of Late Dr Mohammad Iqbal printed by sh Mohammad Ashraf, at the Ashraf Press, 7 Aibak Road Lahore,p.8, Reprinted February 1960

4. See Karen Armstrong's Battle of God. Conclusion of this work portrays so. First published in Great Britain by HarperCollinsPublishers 2000

5. Al-TurqulHukmiyyafissiyasatish-shariyyya, p.14; of Jalundhari, Rashid, Islamic Sharia and its Application with Special Reference to Pakistan, MaktabaJadeed Printing Press Lahore,p.5, First Edition 2003

6. See Kitabulalimwal-mutaalim, p. 5, 6. cf Jalundhari, Rashid, Islamic Sharia and its Application with Special Reference to Pakistan, MaktabaJadeed Printing Press Lahore,p.5, First Edition 2003

7. Malik, Fateh Muhammad, Article: Iqbal's Vision of a Composite MuslimChristian-Jewish Nationalism, Published in Iqbal Review journal of Iqbal Academy, Pakistan April 2003. Also see The Guardian, London, and Thursday, June 20, 2002.

8. Keddie, Nikki, Islamic Response to Western Imperialism, p.103; California library Reprint Series 1983

9. Article, Ahmad Eqbal, Roots of the Religious Right, or see Between Past and Future (Selected Essays on South Asia by Eqbal Ahmad, Oxford University Press, p. 281-282.

10. Iqbal, Muhammad, Reconstruction of Religious Thoughts in Islam, p.146-47. 
11. Iqbal, Muhammad, Reconstruction of Religious Thoughts in Islam, p.126

12. Iqbal, Muhammad, Reconstruction of Religious Thoughts in Islam,p.7

13. Iqbal, Muhammad, Javaid Nama. Shaikh Muhammad Basheer and Sons, Jalaludin Hospital building, Urdu Bazar Lahore.

14. The MuqaddimahIbnKhaldun: translated and introduced by Franz Rosenthal abridged and edited by N.J Dawood, Bollingen series Princeton University Press Princeton and Oxford, p.75.First Princeton Classic Edition with a new introduction by Bruce B. Lawrence, 2005.

15. FazlurRehman, Islam, Anchor Books Doubleday and Company, Inc, Edition 1968, p.2

16. See Hitti, Philip K; History of Arabs from the Earliest Times to Present; fifth edition. London Machmillan and co Ltd 1953 p.118

17. See Hujjat Allah al-Baligha,Cairo 1322 AH,1, $93 \mathrm{ff}$

18. IbnKhaldun, Muqaddima, Engl...

19. FazlurRahman, Islamic Methodology in History, Central Institute of Islamic Research Karachi 1965, p.24

20. Iqbal, Muhammad, Reconstruction of Religious Thoughts in Islam,p.168

21. Ibid. 1:286-287.

22. IbnQayyim al-Jawziyyah, I'lam al-muwaqqi'in(1955), vol .3,p.14

23. FazlurRahman, Islam, p.169

24. See Hitti, Philip K; History of Arabs , p.432

25. Syed Ameer Ali, The Spirit of Islam, Sang e Meel Publications, 2005,p.486-87.

26. Iqbal, Muhammad, Reconstruction of Religious Thought in Islam, p.162. 